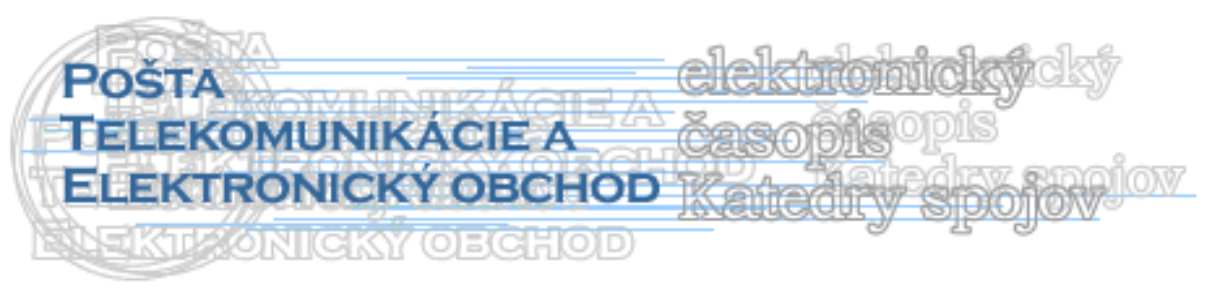

\title{
MARKETINGOVÉ PROSTREDIE PODNIKU
}

\author{
Michal Martinka*, Iveta Kremeňová*
}

\section{Úvod}

Podnik ako ekonomický objekt neexistuje na trhu osamote. Funguje vo vnútri určitého marketingového prostredia, ktoré naň vplýva rôznymi spôsobmi. Či už je to pozitívne, alebo negatívne. Toto prostredie mu poskytuje rôzne príležitosti ale aj hrozby, pričom podnik je nútený eliminovat' svoje slabé stránky a využit' stránky silné na to, aby obstál a dokázal plnit' svoje základné funkcie. Zjednodušene možno marketingové prostredie definovat', ako súhrn faktorov, ktoré ovplyvňujú schopnost' podniku poslúžit' zákazníkom.

Toto prostredie nie je statické, ale výrazne premenlivé v čase. Hlavne okolie podnikov služieb je v poslednom čase vel'mi dynamické, preto je podnik nútený ho neustále sledovat' a reagovat' na zmeny. Na základe týchto informácií vytvárat' základné východiská pre tvorbu a definovanie podnikovej stratégie. Výsledky tejto marketingovej analýzy by mal podnik využit' aj v procese výberu ciel'ového trhu, definovanie jadra svojej činnosti, resp. svojej stratégie a jej následnej implementácie.

Premenlivé prostredie prináša zmeny. Tieto zmeny môžu pôsobit' negatívne (ako ohrozenie), ale často aj pozitívne (ako príležitosti).

Zmeny môžu nastat':

- Pomaly - Pomalé zmeny môžeme predvídat' a dá sa na ne pripravit'. Príkladom pomalej zmeny je odstránenie poštovej výhrady, na ktoré sa napr. Slovenská pošta môže pripravovat' dlhodobo. Pre poštu je to ohrozenie v podobe možnej väčšej konkurencie, ale zároveň aj príležitost' dostat' sa aj na ostatné trhy v rámci EÚ.

- Nárazovo - Pri nárazových zmenách je situácia zložitejšia. Takáto zmena môže mat' na firmu aj likvidačný vplyv. Príkladom nárazovej zmeny môže byt', v podmienkach súčasnej finančnej krízy, zvýšenie deficitu rozpočtu a následné zavádzanie špeciálnych daní, ktoré sa môžu dotýkat' aj poštových operátorov. To by malo za následok zvýšenie cien a pravdepodobne, vplyvom vyšších cien, úbytok zákazníkov a zhoršovanie hospodárenia. Túto situáciu by nemusela zvládnut' čast' konkurencie a z trhu odíst', príležitost'ou by bola možnost' zaplnit' diery, ktoré by ich odchodom vznikli.

\footnotetext{
* Ing. Michal Martinka, externý doktorand, Žilinská univerzita v Žiline tel.: 0902-213 975, e-mail: martinka_michal@pobox.sk

* Doc. Ing. Iveta Kremeňová, PhD., Katedra spojov, F-PEDAS, Žilinská univerzita v Žiline tel.:041/5133100, fax: 041/5655615

e-mail: Iveta.Kremenova@fpedas.uniza.sk
} 
Rozdelenie marketingového prostredia do dvoch základných úrovní:

- 1. Makroprostredie - tvorí širšie okolie podniku. Do určitej miery podniku diktuje, čo a ako môže alebo nemôže robit'. Existujúce makroelementy sú v podstate mimo dosah podnikovej kontroly. Ovplyvňujú postavenie a chovanie podniku a tým aj jeho obchodné úspechy alebo neúspechy a efektívnost' jeho podnikatel'skej činnosti. Napríklad dnešná finančná kríza sa netýka len Slovenskej republiky, ale celého sveta. Tento problém sa nedá riešit' prostredníctvom marketingovej koncepcie, ale firma sa musí postavit' problému a nastavit' svoj systém proti zmenám v makroprostredí.

- 2. Mikroprostredie - tvorí bezprostredné okolie podniku a podnik sám je jeho základným prvkom. I ked' je mikroprostredie do istej miery ovplyvnitel'né a kontrolovatel'né (podnik ho môže ovplyvnit' a kontrolovat' ovel'a lepšie ako makroprostredie, napr. dodávatel'a, ktorý neplní očakávania môže podnik vymenit' za takého, ktorý tieto očakávania bude naplńnat'), napriek tomu aj mikroprostredie diktuje množstvo parametrov, ktoré je nutné zahrnút' do marketingového plánu.

Pričom mikroprostredie sa d'alej môže členit' na:

- 2.1. interné mikroprostredie - súvisí s hospodárskou činnost’ou a firma si ho môže priamo riadit' a nastavit' si parametre, ktoré jej budú vyhovovat'. Do značnej miery závisí od organizačnej štruktúry danej spoločnosti.

- 2.2. externé mikroprostredie - tvoria subjekty, ktoré je možné kontaktovat' na trhu. V tomto prostredí môže podnik ovplyvňovat' jednotlivé jeho prvky iba čiastočne.

Jednotlivé faktory, ktoré ovplyvňujú okolie podniku sú znázornené na obrázku č. 1.

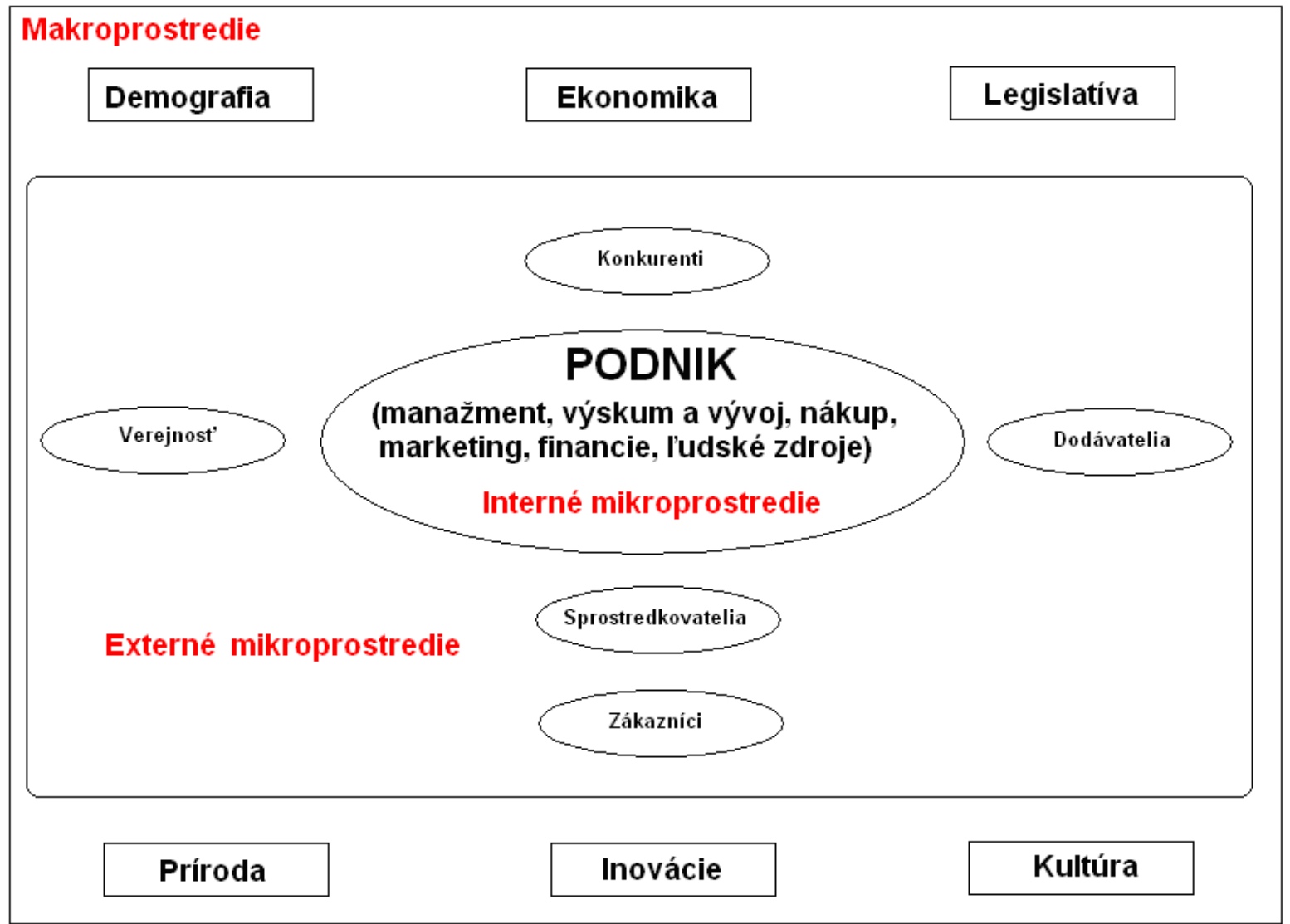

Obrázok č. 1 Marketingové prostredie podniku 


\section{Makroprostredie}

Analýza makroprostredia pomôže podniku odhalit', ako prvky tohto okolia ovplyvnia vel'kost' a rast trhu a jeho jednotlivých segmentov. Analýza jednotlivých zložiek okolia podniku slúži nielen na skúmanie atraktívnosti trhu, ale aj na predvídanie zmien a určovanie stratégie podniku. Faktory okolia určujú aj atraktívnost' trhu. Podnik môže využívat' výhody plynúce z okolia na dosiahnutie svojich vlastných výhod. Okolie, ktoré je náchylné na časté zmeny, sa javí ako atraktívne i riskantné pre podnik.

Makroprostredie je nutné analyzovat' vždy od najväčšieho priestoru po najmenší. Najdôležitejšie sú globálne aspekty, potom údaje súvisiace so zvoleným makroregiónom, následne s vymedzeným trhom, až po jednotlivé národné trhy, prípadne regióny národného trhu, tak ako to je to znázornené na obrázku č. 2. Ide o proces tzv. „lievika“, kde sa vždy postupuje od analýzy najväčšieho priestoru až po základný región.

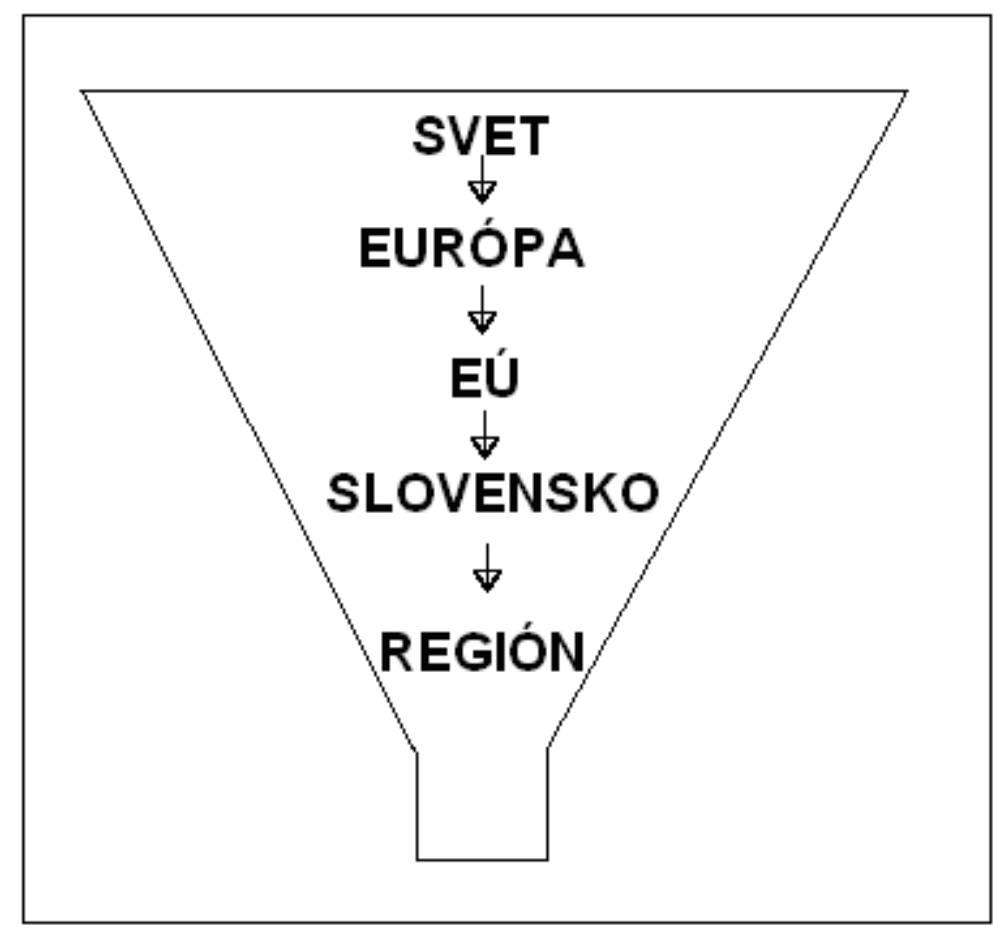

Obrázok č. 2

Tak ako bolo znázornené na obrázku č. 1 na makroprostredie má hlavný vplyv šest' základných oblastí:

\subsection{Demografia}

Označovaná aj ako charakteristika populácie. Patrí sem počet obyvatel'ov, veková štruktúra, priestorové rozmiestnenie, vzdelanie, trendy pôrodnosti a úmrtnosti, migračné tendencie, zmeny v modeloch rodiny, štýl života atd'. V súčasnosti, ked' väčšina populácie vo vyspelom svete starne, je príležitost' pre mnohé firmy upriamit' svoju pozornost' práve na túto skupinu zákazníkov. Môžu to byt' rôzne opatrovatel'ské služby, prípadne poskytovanie dodatočnej zdravotnej starostlivosti. 


\subsection{Ekonomika}

Zahŕňa komplex trendov, ktoré sa týkajú ekonomickej sily vybraného regiónu. Parí sem vývoj niminálnych a reálnych miezd, vývoj životných nákladov, index spotrebitel'ských cien, výška úspor na jedného obyvatel’a, miera nezamestnanosti, miera inflácie, vývoj kurzu, charakter hospodárskeho cyklu atd'. Po prijatí eura v SR vznikli ideálne podmienky pre slovenské firmy na lepšie plánovanie vstupných nákladov a zároveň aj tržieb, pretože sa odstránil vplyv kurzu. Samozrejme môže to byt' aj ohrozenie, pokial' okolité meny oslabujú a okolité štáty získavajú výhodu realizácie svojej produkcie za výhodnejších podmienok, pričom z trhu môže byt' cenovo vytlačená slovenská produkcia.

\subsection{Legislatíva}

Sústava zákonov, predpisov a vyhlášok, ktoré musí podnik rešpektovat', pokial' chce podnikat' na danom trhu. Legislatíva reguluje spôsob komunikácie s dodávatel'mi, zákazníkmi, vymedzuje záväzky voči zákazníkovi, štátu a spoločnosti, ale aj zamestnancom, životnému prostrediu atd'. Vstupom SR do EÚ museli byt' mnohé právne normy prispôsobené európskym, čo tiež prinieslo mnoho príležitosti, ale zároveň aj hrozieb pre podniky pôsobiace na slovenskom trhu.

\subsection{Príroda}

Zahrňuje hlavne prírodné podmienky, ale aj prírodné zdroje. Môžeme sem zaradit' napr. klímu, na ktorej je závislá úspešnost' pol’nohospodárstva, kvalitu životného prostredia, ktorá je vel'mi dôležitá pri cestovnom ruchu. Pri výrobných odvetviach je dôležitý dostatok prírodných zdrojov, či už nerastných surovín (uhlie, ropa), alebo pri drevospracujúcom priemysle dostatok drevnej hmoty. Prírodným podmienkam je nutné sa prispôsobit', hlavne pri poskytovaní služieb pod holým nebom, pretože tam ani dokonalá ponuka služieb nepriláka spotrebitel'a. Príkladom môže byt' lyžiarske stredisko, prípadne kúpalisko.

\subsection{Inovácie}

Ide o technologické prostredie, ktoré výrazne ovplyvňuje inováciu existujúcich i vznik nových služieb. Inovačné príležitosti sú prakticky neobmedzené, preto vel'ké firmy investujú vel'ké prostriedky do výskumu a vývoja, čo im dáva konkurenčnú výhodu. Ale okrem príležitostí predstavujú inovácie aj hrozby, pretože pokial' napr. automobilový priemysel prejde na pohon elektrickou energiou a táto technológia sa zdokonalí tak, že bude výrazne výhodnejšia pre spotrebitel'a, tak potom je to hrozba pre petrochemický priemysel, pretože sa zníži predaj benzínu a nafty.

\subsection{Kultúra}

Vplyv sociálno-kultúrneho prostredia výrazne ovplyvňuje celkový charakter spotrebitel'ského chovania. Pre niektoré národy je dôležitá kultúrna tradícia, pre iných je to náboženstvo, pre niekoho iného zas rodina. V súčasnosti nastávajú v prostredí globalizácie mnohé zásadné zmeny, postupne sa presadzuje emancipácia žien aj v krajinách, kde to v minulosti nebolo možné. Zvýrazňuje sa vplyv zdravého spôsobu života. Aj na tieto vplyvy treba mysliet' pri analýze marketingového prostredia. 


\section{Mikroprostredie}

Podobne ako v makroprostredí podnikov, aj vich mikroprostredí prebehli v posledných dekádach dvadsiateho storočia výrazné zmeny. Tieto zmeny prebiehajú na rôznych úrovniach a rôznych oblastiach. Možno ich vnímat' z pohl'adu trhu, na ktorom podnik pôsobí, alebo z pohl'adu konkurenčného postavenia v odvetví. Mikroprostredie možno delit' na:

\subsection{Interné mikroprostredie}

Toto prostredie si každá firma dokáže, v určitom časovom horizonte, regulovat' podl'a potreby. Je závislé od organizačnej štruktúry, takže sem patrí napr.: manažment, výskum a vývoj, nákup, marketing, financie a l'udské zdroje. Pozornost' mu je nutné venovat', až po celkovej analýze makroprostredia a externého mikroprostredia.

\subsection{Externé mikroprostedie}

Rozlišujeme jeho nasledujúce základné súčasti:

2.2.1 Zákazníci - si zaslúžia hlavnú pozornost'. Musia sa plnit' ich priania a potreby, za podmienky plnenia ciel'ov podniku. Pri analýze je vhodné zákazníkov najskôr rozdelit' do skupín:

- spotrebitelia - nakupujú pre vlastnú potrebu

- výrobcovia - nakupujú produkty za účelom d’alšieho spracovania

- obchodníci - nakupujú produkty na to, aby ich mohli so ziskom predat'

- štát - nakupujú produkty pre plnenie verejných služieb

- zahraniční zákazníci - ktokol’vek, kto má sídlo v cudzom štáte

2.2.2 Konkurenti - sú to firmy, ktoré sa usilujú o tie isté, resp. podobné ciele. Vzájomné súperenie medzi firmami vytvára konkurenciu.

2.2.3 Sprostredkovatelia - sú to firmy, ktoré vstupujú medzi podnik a zákazníka. Mali by pomáhat' spoločnosti sa presadit' na trhu. Predovšetkým ide o sprostredkovatel'ov, ktorí sú zúčastnení na distribúcii tovarov a služieb.

2.2.4 Dodávatelia - sú to firmy, ktoré ponúkajú zdroje nutné pre našu činnost'. Môže sa jednat' o vstupy do výrobného procesu, ako napr. suroviny, materiál, polotovary, práce, energie, alebo aj o ponuku iných zdrojov, ako napr.: stroje a zariadenie, dopravné prostriedky, vybavenie pracoviska a iné služby potrebné pre činnost' spoločnosti.

2.2.5 Verejnost' - pod týmto pojmom môžeme rozumiet' osoby a organizácie, ktoré s podnikom nemajú obchodnú väzbu, ale napriek tomu majú výrazný vplyv na činnost' firmy. Preto je vhodné uskutočňovat' kroky smerujúce k vytváraniu obojstranne prospešných vzt'ahov. Preto má väčšina vel'kých firiem oddelenia, ktoré sa zaoberajú vzt'ahmi s verejnost'ou. 


\section{Záver}

Dostatočná znalost' marketingového prostredia umožní podniku správne zvolit' marketingovú stratégiu. Táto následne napomôže k dosiahnutiu stanovených ciel'ov, či už je to zvyšovanie tržieb, trhového podielu alebo zisku, prípadne znižovanie nákladov. Práve z tohto dôvodu je nutné venovat' dostatočnú pozornost' analýze okolia podniku.

\section{Literatúra}

[1] ĎAĎO, J. - PETROVIČOVÁ J. - KOSTKOVÁ M.: Marketing služieb, EPOS - Ing. Miroslav Mračko, Bratislava 2006, ISBN 80-8057-662-9

[2] HORÁKOVÁ, H. : Strategický marketing, 2. rozšírené a aktualizované vydanie, Grada Publishing a.s., Praha 2003, 204 str., ISBN 80-247-0447-1

[3] ROSTAŠOVÁ M. - KREMEŇOVÁ I.: Marketing v službách - Algoritmy marketingových činností, EDIS - vydavatel'stvo ŽU, Žilina 2005, ISBN 80-8070-355-8

[4] KOZEL R.: Moderní marketingový výskum, Grada Publishing, a.s., Praha 2006, ISBN 80-247-0966-X

[5] Eisler, J. - Výkladový ekonomický slovník podnikatel’a, Poradca s.r.o., Martin 2003, ISBN 80-88927-53-6 